\title{
Rotary Club, clubes da elite, um tipo ideal de profissional e a relação com o Estado
}

\author{
Alessandro Cavassin Alves ${ }^{1}$
}

O artigo de Dominique Connan (Uma reinvenção da diferença elitista: um Rotary Clube no Quênia de Mwai Kibaki ${ }^{2}$ ) aponta para a relevância em se pesquisar clubes frequentados pelas elites, neste caso, profissionais liberais, tendo como referência a participação no Rotary Club Nairobi-Langata ${ }^{3}$, na capital do Quênia, país na África Oriental com as suas dinâmicas econômicas, sociais e políticas próprias e as relações dos rotarianos com o Estado queniano. Neste sentido, o autor participou das reuniões semanais do Rotary Club, entre 2008 a 2011, numa pesquisa etnográfica.

Ao longo do texto Connan descreve a importância do clube para esta "geração de elite", muitos deles filhos e filhas de rotarianos, de jovens profissionais que ascenderam em suas carreiras. $E$, ao final do artigo há uma interessante lista com 42 nomes desses rotarianos mais ativos do Langata entre 2008-2011, apresentando algumas "propriedades sociais" desses membros, como a profissão, formação, escolaridade e onde estudaram, e se o pai foi ou era membro de um Rotary; enfim, esta é uma elite econômica e social queniana que opta por reunir-se semanalmente para encontros que visam a formação pessoal, a socialização e a filantropia; outro ponto interessante dessa lista é de que o autor destaca a dificuldade de "precisar a pertença étnica" dos sócios, pois "muitos rotarianos de Langata tem pais originários de diferentes regiões", sinalizando, aparentemente, que o clube não impede o acesso de pessoas de etnias diversas, mas priorizando a característica da atividade profissional. Isto é importante, devido a história dos conflitos étnicos existentes no país.

Assim, outro ponto em destaque no artigo, é como se dá o relacionamento desses rotarianos com o Estado queniano, ou mesmo o que eles pensam como deveria ser a política, a partir do modelo de profissionais liberais que assumem ser. Afinal, o autor deixa claro que sua pesquisa se deu durante o

\footnotetext{
${ }^{1}$ Graduado em Ciências Sociais pela Universidade Federal do Paraná. Mestrado e Doutorado em Sociologia pela UFPR. Atua como docente compondo o Quadro Próprio do Magistério no Governo do Estado do Paraná e na Faculdade São Basílio Magno e UNIANDRADE. Endereço eletrônico: alessandrocavassin@gmail.com

${ }^{2}$ Texto original «Une réinvention de la différence élitaire : un Rotary Club dans le Kenya de Mwai Kibaki», Critique internationale, vol. 73, № 4, 2016, p. 133-155. Disponível em https://www.cairn.info/revue-critique-internationale-2016-4-page-133.htm. Acesso 25.outubro.2017.

${ }^{3}$ Rotary Club of Nairobi-Langata. Disponível em: http://www.rotarycluboflangata.org/. Acesso em 19/12/2017.
} 
período do governo do presidente Mwai Kibaki, no sentido de que a vida no Quênia tem como referência muito forte os acontecimentos políticos, e isto tudo, por exemplo, pós os fatídicos atos de violências póseleitorais de $2007 / 2008^{4}$, dados em função de critérios políticos, alegando fraudes nas eleições, ou mesmo étnicos ${ }^{5}$, com a morte de aproximadamente mil pessoas, além de milhares de refugiados, e com a tentativa de um governo de coalizão pós 2008 exigido pela comunidade internacional. Mwai Kibaki teria sido eleito em 2002 em torno "de um programa resolutamente liberal", mas acabou seguindo a tradição autoritária de seus antecessores, bem como, recorrendo às fraudes eleitorais. Afinal, as instabilidades políticas prejudicam negócios, por vezes, representados pelos profissionais participantes do Rotary Club.

A partir do século XIX, o Quênia ${ }^{6}$ tornou-se um protetorado inglês, uma colônia, mas conseguindo sua independência política em 12/12/1963, passando a ter um regime político presidencialista, mas com um poder executivo centralizador e forte, destacando-se, assim, as figuras dos presidentes da república, que por sua vez governam por longos períodos. Os presidentes quenianos foram: Jomo Kenyatta (entre 1964-1978 - ano de seu falecimento); Kalenjin Daniel arap Moi (entre 1978-2002), considerado um ditador; nas eleições de 2002, vitória do oposicionista Mwai Kibaki (entre 2002-2013), mas nas eleições de 2007, perpetuaram-se as fraudes que levaram aos conflitos armados, sendo líder da oposição Raila Odinga; nas eleições de 2012, Mwai Kibaki com 81 anos não concorre, sendo eleito Uhuru Kenyatta (entre 2013presente), filho de Jomo Kenyatta, mesmo acusado de crimes contra a humanidade, devido ao conflito político-étnico de 2007-2008, e Raila Odinga novamente foi derrotado em possíveis eleições fraudadas

O Quênia, pós independência, acabou tendendo para um sistema econômico aberto às potências capitalistas, "pró-ocidental" e, por sua vez, "anticomunista", diferente de outros países que acabaram optando pela via socialista, o que, de certa forma, favorecia a organização de clubes de caráter liberal, como o Rotary Club. O Rotary Club segue um padrão mundial de organização, fundado em Chicago, Estados Unidos, em 1905, pelo advogado Paul Harris, com objetivos de reunir associados "para trocar ideias, criar amizades, fazer contatos profissionais e trabalhar pelo bem de comunidades locais e internacionais"; atualmente conta com 1,2 milhão de associados e mais de 35.000 clubes $^{8}$.

4 Wikipedia. The Free Encyclopedia. Article: 2007-08 Kenyan crisis. Disponível em: https://en.wikipedia.org/wiki/2007\%E2\%80\%9308 Kenyan crisis. Acesso em 19/12/2017.

${ }^{5}$ Centro Regional de Informação das Nações Unidas. UNRIC: Quénia: violência de 2007-2008 foi planeada, segundo Procurador do TPI. Disponível em: http://www.unric.org/pt/actualidade/27583-quenia-violencia-de-2007-2008-foi-planeada-segundo-procuradordo-tpi. Acesso em 19/12/2017.

${ }^{6}$ História geral da África, VIII: África desde 1935. Editado por Ali A. Mazrui e Christophe Wondji. Brasília: UNESCO, 2010: Quênia, p. 277-285.

7 Uhuru Kenyatta é eleito presidente do Quênia. Disponível em: http://g1.globo.com/mundo/noticia/2013/03/uhuru-kenyata-eeleito-presidente-do-quenia.html. Acesso em 19/12/2017. E com novas confusões nas eleições de 2017, mas que deu a vitória a Uhuru Kenyatta, novamente. Disponível em: https://g1.globo.com/mundo/noticia/baixo-comparecimento-na-repeticao-daseleicoes-do-quenia-abala-esperanca-de-uniao-do-pais.ghtml. Acesso em 19/12/2017.

${ }^{8}$ Rotary. Disponível em: https://www.rotary.org/pt/. Acesso em 19/12/2017. 
Portanto, o Quênia atual é de Uhuru Kenyatta. E as elites econômicas e profissionais quenianas têm de conviver com uma democracia ainda sujeita a fraudes e a governos nepóticos e corruptos, em oposição ao que os rotarianos desejariam que fosse, um governo nos moldes de uma empresa, racional, empreendedora e burocrática; e a força dos grupos étnicos, que formam essa nação, ainda é presente e visível, principalmente quando são convocados a votarem, divisão visível, também, no interior do clube, demonstrado nas notas de campo de Dominique Connan, mas que não impede a convivência e a realização dos objetivos específicos entre eles. O Rotary Club não pretende ser um clube de oposição política ou um partido político, mas consegue juntar membros diversos, com determinada influência e poder aquisitivo, que podem, naturalmente, também pensar e se posicionar politicamente, inclusive sendo eleitos ou de pertencerem a cargos públicos, e juntos tem potencial para agirem em prol do social, principalmente com seus projetos filantrópicos.

Enfim, os clubes das elites e suas relações com o Estado fazem parte de uma importante agenda de pesquisa que por sua vez é esquecida pelos cientistas sociais. 